\title{
Albumin Concentrations Are Primarily Determined by the Body Cell Mass and the Systemic Inflammatory Response in Cancer Patients With Weight Loss
}

\author{
Donald C. McMillan, Walter S. Watson, Patricia O'Gorman, \\ Tom Preston, Hazel R. Scott, and Colin S. McArdle
}

\begin{abstract}
The association between hypoalbuminemia and poor prognosis in patients with cancer is well recognized. However, the factors that contribute to the fall in albumin concentrations are not well understood. In the present study, we examined the relationship between circulating albumin concentrations, weight loss, the body cell mass (measured using total body potassium), and the presence of an inflammatory response (measured using $C$-reactive protein) in male patients $(\mathrm{n}=40)$ with advanced lung or gastrointestinal cancer. Albumin concentrations were significantly correlated with the percent ideal body weight $(\mathrm{r}=0.390, \mathrm{p}<$ $0.05)$, extent of reported weight loss $(\mathrm{r}=-0.492, \mathrm{p}<0.01)$, percent predicted total body potassium (adjusted for age, height, and weight, $\mathrm{r}=0.686, \mathrm{p}<0.001)$, and $\log _{10} C$ reactive protein concentrations $(\mathrm{r}=-0.545, \mathrm{p}<0.001)$. On multiple regression analysis, the percent predicted total body potassium and $\log _{10} C$-reactive protein concentrations accounted for $63 \%$ of the variation in albumin concentrations $\left(\mathrm{r}^{2}=0.626, \mathrm{p}<0.001\right)$. The interrelationship between albumin, body cell mass, and the inflammatory response is consistent with the concept that the presence of an ongoing inflammatory response contributes to the progressive loss of these vital protein components of the body and the subsequent death of patients with advanced cancer.
\end{abstract}

\section{Introduction}

The prognostic value of hypoalbuminemia in patients with advanced cancer has long been recognized $(1,2)$. However, only recently have the factors that influence its concentration been better understood. In healthy adult men, albumin concentrations have been shown to correlate with lean tissue as derived from anthropometric measurements (3). Previously, in cancer patients it had been thought that low circulating al- bumin concentrations were due to reduced synthesis (4) or increased transcapillary escape rates (5). However, it has been recently reported that the rate of albumin synthesis is similar to that of healthy subjects in the fasted (6) and fed state (7) and that transcapillary escape rates are within the normal range (8). This would suggest that albumin degradation plays an important role in the hypoalbuminemia of the cancer patient $(6,7)$.

It is well known that, as part of the inflammatory response to acute injury, albumin concentrations fall as those of other acute-phase proteins, such as C-reactive protein, rise (1). More recently, a similar inverse relationship has been reported in advanced gastrointestinal and lung cancer patients $(9,10)$.

The aim of the present study was to examine the relationship and interdependence between albumin concentrations, total body potassium (adjusted for age, height, and weight), and the presence of a systemic inflammatory response in male cancer patients.

\section{Materials and Methods}

\section{Study Design}

Male patients with locally advanced or metastatic cancer were studied. No patient had undergone surgery, radiotherapy, or chemotherapy in the previous two months. No patient complained of moderate or severe dysphagia, and none had obvious functional obstruction to food intake or abnormal liver function tests.

Patients were questioned carefully about their weight and any weight loss they had experienced. Age, height, and weight were recorded together with measurement of total body potassium. Venous blood samples were taken for rou-

D. C. McMillan and P. O'Gorman are affiliated with the University Department of Surgery, Royal Infirmary, Glasgow G31 2ER, UK. W. S. Watson is affiliated with the Nuclear Medicine Department, Southern General National Health Service Trust, Glasgow G51 4TF, UK. T. Preston is affiliated with the Isotope Biochemistry Laboratory, Scottish Universities Environmental Research Centre, East Kilbride, Glasgow G75 OQF, UK. H. R. Scott is affiliated with the Department of Respiratory Medicine, Stobhill National Health Service Trust, Glasgow G21 3UW, UK. C. S. McArdle is affiliated with the University Department of Surgery, Royal Infirmary, Edinburgh EH3 9YW, UK. 
tine laboratory measurement of albumin, C-reactive protein, and hematocrit. The study was approved by the local hospital ethical committee. All patients gave written informed consent.

\section{Methods}

Height (to the nearest $\mathrm{cm}$ ) and weight (to the nearest 0.1 $\mathrm{kg}$ ) were measured using a stadiometer and beam-balance standing scale (Weylux, Cambridge, UK). Body weight was expressed as a percentage of the reported preillness weight and as a percentage of the ideal body weight (defined by a body mass index of $23 \mathrm{~kg} / \mathrm{m}^{2}$ ).

Albumin concentrations were measured using the bromcresol green method on a Technicon RA-1000 automated analyzer (Technicon, Tarrytown, NY).

C-reactive protein was measured by fluorescence polarization immunoassay using an Abbott TDX analyzer and Abbott reagents (Abbott Laboratories, Abbott Park, IL). The limit of detection of the assay is a C-reactive protein concentration of $<5 \mathrm{mg} / \mathrm{l}$.

Hematocrit was measured following a standard technique on a flow cytometer (model S-Plus STKR, Coulter, Luton, UK).

Total body potassium was determined by measuring the amount of the naturally occurring radioisotope, ${ }^{40} \mathrm{~K}$, in each patient using a whole body counter (11).

The coefficient of variation for these methods, over the range of measurement, was $<5 \%$.

\section{Calculations}

Total body potassium values were expressed as a percentage of predicted normal values to adjust for variations in age, height, and weight, as previously described (11).

Data are presented as median and range. Regression analysis was performed using a linear model of patients' albumin with percent ideal body weight, percent weight loss, percent predicted total body potassium, and C-reactive protein as variables. As the distribution of C-reactive protein concentrations was skewed, they were logarithmically transformed before analysis. Concentrations of C-reactive protein below the threshold of sensitivity of the assay $(5 \mathrm{mg} / \mathrm{l})$ were expressed as equal to this threshold.

Multivariate regression analysis was performed using a stepwise backward procedure to derive a final model of the variables that had a significant independent relationship with albumin. To remove a variable from the model, the corresponding $P$ value had to be $>0.05$.

Analysis was performed using SPSS software (SPSS, Chicago, IL).

\section{Results}

Characteristics of the 40 male cancer patients ( 12 esophagus, 7 stomach, 3 pancreas, 7 colon, and 11 non-small cell lung cancer) are shown in Table 1 . Thirty-seven patients had
Table 1. Characteristics of Male Cancer Patients ${ }^{a}$

\begin{tabular}{lcl}
\hline Characteristic & \multicolumn{2}{c}{ Median (Range) } \\
\hline Age, yr & 69 & $(48-76)$ \\
Height, cm & 172 & $(158-185)$ \\
Weight, kg & 60.2 & $(38.7-98.7)$ \\
Ideal body weight, \% & 87.9 & $(58.2-143.4)$ \\
Weight loss, \% & 15 & $(0-42)$ \\
Albumin, g/l & 40 & $(26-46)$ \\
C-reactive protein, mg/1 & 18 & $(<5-170)$ \\
Hematocrit, \% & 36.4 & $(24.5-44.5)$ \\
Total body potassium, mmol & 2,330 & $(1,500-3,876)$ \\
Total body potassium, \%predicted & 86.3 & $(50.1-98.8)$ \\
\hline$a: n=40$. & &
\end{tabular}

locally advanced and three patients had metastatic disease. The median weight loss relative to preillness weight of the patients was $15 \%$; this was associated with a $12 \%$ reduction in ideal body weight. Body cell mass (as measured by total body potassium) was significantly lower than that predicted $(p<0.001)$.

Albumin concentrations were significantly correlated with percent ideal body weight $(r=0.390, p<0.05)$, percent weight loss $(r=-0.492, p<0.01)$, percent predicted total body potassium (adjusted for age, height, and weight; $r=$ $0.686, p<0.001$; Figure 1$)$, and $\log _{10}$ C-reactive protein concentrations $(r=-0.545, p<0.001$; Figure 2$)$.

On multiple regression analysis, only the percent predicted total body potassium and $\log _{10} \mathrm{C}$-reactive protein concentrations remained significant at the 5\% level. Together, total body potassium and $\log _{10} \mathrm{C}$-reactive protein accounted for $63 \%$ of the variation in albumin concentrations $\left(r^{2}=\right.$ $0.626, p<0.001)$.

\section{Discussion}

Cancer cachexia is characterized by progressive involuntary weight loss, loss of body cell mass, muscle weakness, and fatigue. Although overt cachexia is clinically apparent, minimal weight loss is frequently overlooked. In such patients, a number of nutritional indexes are recognized to provide prognostic information (12). These include albumin, and, indeed, in cancer patients, measurements are often restricted to weight and albumin. However, it is not clear what these changes in albumin concentration reflect.

Previous studies in small numbers of patients, using nonreference methods, suggested an association between albumin concentrations and body cell mass $(10,13)$. The present study, using total body potassium as the reference method, confirms that albumin concentrations correlate with body cell mass. Furthermore, it was of interest that in the present study there was a significant inverse correlation between circulating concentrations of albumin and C-reactive protein, the magnitude of which was similar to that previously reported $(9,13)$. On multiple regression analysis, body cell mass and the systemic inflammatory response were in- 


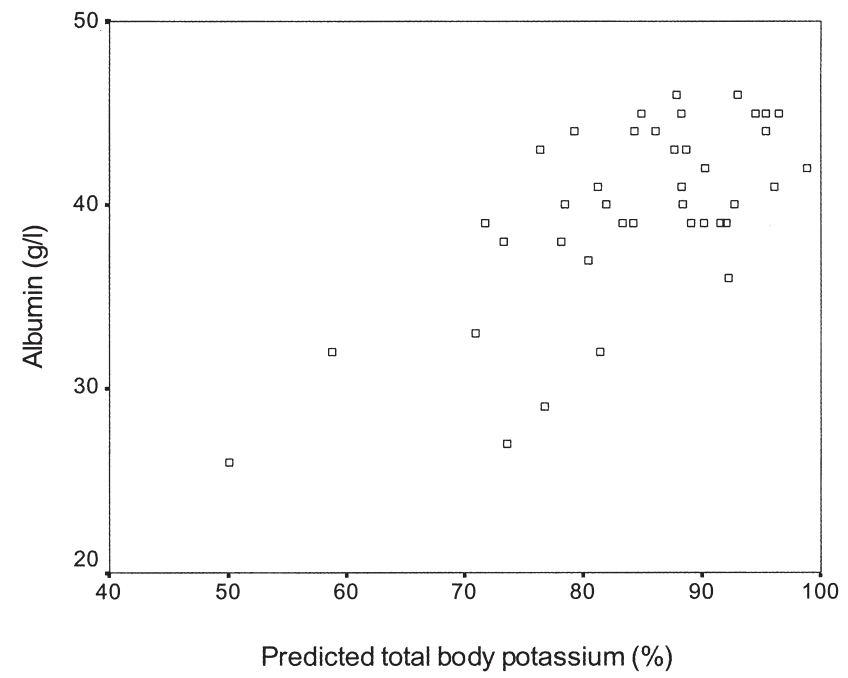

Figure 1. Relationship between albumin concentration and measured, as percentage of predicted, total body potassium in cancer patients with weight loss.

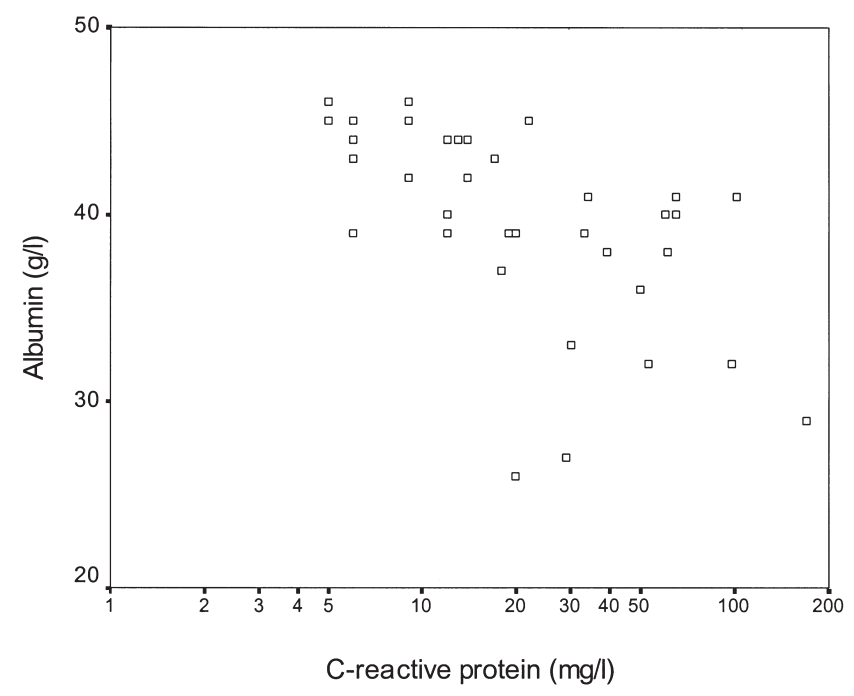

Figure 2. Relationship between albumin concentration and C-reactive protein concentration in cancer patients with weight loss.

dependently correlated with circulating albumin concentrations. Indeed, when total body potassium (adjusted for body habitus) and the inflammatory response were considered, they accounted for $\sim 65 \%$ of the variation in albumin concentration. This paradigm gives us a better understanding of the factors underlying hypoalbuminemia in cancer patients.

It is of interest that the inflammatory response in cancer patients is not only associated with a reduction in circulating albumin concentrations, probably through increased degradation $(6,7)$ but, over time, is also associated with the loss of body cell mass (14). Therefore, it may be that the inflammatory response, with its increased demand for specific amino acids for mediator and acute-phase protein synthesis and immune and antioxidant defenses $(7,15,16)$, promotes the degradation of available body protein, including albumin, and body cell mass. The modest pool size of albumin relative to that of body cell mass may be reflected in its loss becoming noticeable at an earlier stage. With respect to the loss of body cell mass, it would appear that this is primarily of skeletal muscle due to net skeletal muscle catabolism (17). These changes over a prolonged period result in the nutritional decline that leads to death of the cancer patient (2).

Considering the prognostic value of albumin in cancer patients and the results of the present study, one might speculate that improving the prognosis of such patients will require moderation of the inflammatory response and maintenance/restoration of body cell mass. Recent work has indicated that the inflammatory response can be moderated in the weight-losing gastrointestinal cancer patient $(18,19)$. However, it is not clear whether such an approach will prevent the loss of body cell mass in such patients.

In this study, low albumin concentrations in male cancer patients reflect loss of body cell mass and the presence of an inflammatory response. The interrelationship between albumin, body cell mass, and the inflammatory response is consistent with the concept that the presence of an ongoing systemic inflammatory response contributes to the progressive loss of these vital protein components of the body and the subsequent death of patients with advanced cancer.

\section{Acknowledgments and Notes}

The authors gratefully acknowledge the interest and encouragement of Prof. T. G. Cooke. The authors also thank Dr. Wilson Angerson for statistical advice and the staff of the Nuclear Medicine Department, Southern General Hospital. Address correspondence to Dr. D. C. McMillan, University Dept. of Surgery, Royal Infirmary, Glasgow G31 2ER, UK. Phone: 0141211 5435. FAX: 0141552 3229. E-mail: d.c.mcmillan@ clinmed.gla.ac.uk.

Submitted 21 November 2000; accepted in final form 29 January 2001.

\section{References}

1. Margarson, MP, and Soni, N: Serum albumin: touchstone or totem? Anaesthesia 53, 789-803, 1998.

2. O'Gorman, P, McMillan, DC, and McArdle, CS: Factors predicting survival of advanced gastrointestinal cancer patients with weight loss. Nutr Cancer 37, 36-40, 2000.

3. Micozzi, MS, Albanes, D, and Stevens, RG: Relation of body size and composition to clinical biochemical and haematologic indexes in United States men and women. Am J Clin Nutr 50, 1276-1281, 1989.

4. Heinrich, PC, Castell, JV, and Andus, T: Interleukin-6 and the acute phase response. Biochem J 265, 621-636, 1990.

5. Fleck, A, Raines, G, Hawker, F, Trotter, J, Wallace, PI, et al.: Increased vascular permeability: a major cause of hypoalbuminaemia in disease and injury. Lancet 1, 781-784, 1985.

6. Fearon, KCH, Falconer, JS, Slater, C, McMillan, DC, Ross, JA, et al.: Albumin synthesis rates are not decreased in hypoalbuminaemic cachectic cancer patients with an ongoing acute phase protein response. Ann Surg 227, 249-254, 1998.

7. Barber, MD, Fearon, KC, McMillan, DC, Slater, C, Ross, JA, et al.: Liver export protein synthetic rates are increased by oral meal feeding in weight-losing cancer patients. Am J Physiol Endocrinol Metab 279, E707-E714, 2000.

8. Ballmer, PE, Ochsenbein, AF, and Schutz-Hofmann, S: Transcapillary escape rate of albumin positively correlates with plasma albumin concentration in acute but not in chronic inflammatory disease. Metabolism 43, 697-705, 1994. 
9. O'Gorman, P, McMillan, DC, and McArdle, CS: Impact of weight loss, appetite and the inflammatory response on quality of life in gastrointestinal cancer patients. Nutr Cancer 32, 76-80, 1998.

10. Simons, JPFHA, Schols, AMWJ, Buurman, WA, and Wouters, EFM: Weight loss and low body cell mass in males with lung cancer: relationship with systemic inflammation, acute-phase response, resting energy expenditure, and catabolic and anabolic hormones. Clin Sci 97, 215-223, 1999.

11. Watson, WS, McMillan, DC, Chaudhuri, A, and Behan, PO: Resting energy expenditure is increased in potassium-containing tissues in subjects with chronic fatigue syndrome. J Chronic Fatigue Syndrome 4, 3-14, 1998.

12. Schneider, SM, and Hebuterne, X: Use of nutritional scores to predict clinical outcomes in chronic diseases. Nutr Rev 58, 31-38, 2000.

13. Barber, MD, Ross, JA, and Fearon, $\mathrm{KCH}$ : Changes in nutritional, functional and inflammatory markers in advanced pancreatic cancer. Nutr Cancer 35, 106-110, 1999.
14. McMillan, DC, Scott, HR, Watson, WS, Preston, T, Milroy, R, et al.: Longitudinal study of body cell mass depletion and the inflammatory response in cancer patients. Nutr Cancer 31, 101-105, 1998.

15. McMillan, DC, Preston, T, Fearon, KCH, Burns, HJG, Slater, C, et al.: Protein synthesis in cancer patients with an inflammatory response: investigations using $\left[{ }^{15} \mathrm{~N}\right]$ glycine. Nutrition 10, 232-240, 1994.

16. Preston, T, Slater, C, McMillan, DC, Falconer, JS, Shenkin, A, et al.: Fibrinogen synthesis in fasted cancer patients with an acute phase response. J Nutr 128, 1355-1360, 1998.

17. Kotler, DP: Cachexia. Ann Intern Med 133, 622-634, 2000.

18. McMillan, DC, Wigmore, SJ, Fearon, KCH, O'Gorman, P, Wright, $\mathrm{CE}$, et al: A prospective randomised study of megestrol acetate and ibuprofen in gastrointestinal cancer patients with weight loss. $\mathrm{Br} J$ Cancer 79, 495-500, 1999.

19. Fearon, KCH, Barber, MD, Falconer, JS, McMillan, DC, Ross, JA, et al.: Pancreatic cancer as a model: inflammatory mediators, acute phase response and cancer cachexia. World J Surg 23, 584-588, 1999. 
Copyright of Nutrition \& Cancer is the property of Lawrence Erlbaum Associates and its content may not be copied or emailed to multiple sites or posted to a listserv without the copyright holder's express written permission. However, users may print, download, or email articles for individual use. 